\title{
PERBEDAAN PERUBAHAN WARNA RESIN KOMPOSIT PADA PERENDAMAN MINUMAN SARI BUAH PABRIK DAN SARI BUAH SEGAR
}

\author{
${ }^{1}$ Claudya F. Kaunang \\ ${ }^{2}$ P. S. Anindita \\ ${ }^{2}$ Michael A. Leman
${ }^{1}$ Kandidat Skripsi Program Studi Pendidikan Dokter Gigi Fakultas Kedokteran
${ }^{2}$ Program Studi Pendidikan Dokter Gigi Fakultas Kedokteran
Universitas Sam Ratulangi Manado
Email: claudyafk.ck@gmail.com

\begin{abstract}
Composite resin has a lot advantages compared with other filling materials, this is because composite resin has mechanical strength and good aesthetic properties. However, the composite resin also has a disadvantage that can be discoloration during usage caused by extrinsic factors. One of the extrinsic factors is absorption of food and beverages' dye. Beverage such as fruit juice can cause discoloration of the composite. This study aimed to determine the discoloration of the composite resin when it was immersed in fruit juice. This was an experimental study with a pretest and posttest group design. There were10 samples of composite resin circle formed with a thickness of $2 \mathrm{~mm}$ and a diameter of $5 \mathrm{~mm}$, divided in 2 groups: group I was immersed in fresh fruit juice and group II was immersed in factory fruit juice factory until days 9 . On days 3,6 , and 9 , samples were tested for discoloration by using a spectrophotometer. The results showed color changes in the samples immersed in factory fruit juice more intense than samples immersed in fresh fruit juice. The $\mathrm{T}$ test results showed a significant difference in color changes between composites immersed in factory fruit juice and composites immersed in fresh fruit juice on days 3, 6, and 9 ( $\mathrm{p}<0.05)$.
\end{abstract}

Keywords: composite resin, discoloration, fruit juice

\begin{abstract}
Abstrak: Resin komposit memiliki banyak kelebihan dibandingkan dengan bahan tumpatan lainnya karena tumpatan resin komposit memiliki kekuatan mekanik dan sifat estetik yang bagus. Resin komposit juga memiliki kekurangan yaitu dapat mengalami perubahan warna selama pemakaian yang disebabkan oleh faktor ekstrinsik yaitu adanya absorbsi zat warna dari makanan maupun minuman. Minuman yang dapat menyebabkan perubahan warna pada komposit salah satunya ialah minuman sari buah. Penelitian ini bertujuan untuk mengetahui perubahan warna resin komposit pada perendaman minuman sari buah. Penelitian ini menggunakan metode eksperimental murni dengan rancangan pretest and posttest group design. Terdapat 10 sampel resin komposit yang berbentuk lingkaran dengan tebal $2 \mathrm{~mm}$ dan diameter $5 \mathrm{~mm}$, dibagi dalam 2 kelompok yakni kelompok I, direndam dalam sari buah pabrik dan kelompok II, direndam dalam sari buah segar sampai hari ke-9. Pada hari ke-3, 6, dan 9 sampel diuji perubahan warna dengan menggunakan alat spektrofotometer. Hasil penelitian menunjukkan perubahan warna sampel yang direndam dalam sari buah pabrik lebih besar dibandingkan sampel yang direndam dalam sari buah segar. Hasil uji t menunjukkan adanya perubahan yang bermakan dari resin komposit pada pengukuran hari ke-3, 6, 9 antara kelompok perendaman sari buah pabrik dan kelompok perendaman sari buah segar dengan $\mathrm{p}<0,05$.
\end{abstract}

Kata kunci: resin komposit, perubahan warna, minuman sari buah 
Seiring perkembangan ilmu pengetahuan dan teknologi, kebutuhan dan tuntutan pasien akan bahan restorasi sewarna gigi yang dapat mengganti struktur gigi semakin tinggi. Resin komposit merupakan salah satu bahan restorasi sewarna gigi yang banyak digunakan di bidang kedokteran gigi sebagai bahan tumpatan saat ini karena memiliki nilai estetik yang tinggi dibandingkan dengan bahan tumpatan warna gigi yang lain. Resin komposit digunakan untuk menggantikan struktur gigi yang hilang, memodifikasi warna dengan gigi yang ada, dan dapat mengembalikan fungsi gigi. ${ }^{1}$

Resin komposit sebagai bahan tumpatan memiliki kelebihan dan kekurangan, di antaranya perubahan warna yang disebabkan oleh faktor intrinsik dan faktor ekstrinsik. Faktor intrinsik dapat berasal dari bahan resin itu sendiri, sedangkan faktor ekstrinsik berasal dari makanan atau minuman berwarna yang dikonsumsi, misalnya kopi, teh, cola, dan minuman ringan lainnya. ${ }^{2}$

Minuman ringan atau softdrink merupakan minuman yang tidak mengandung alkohol. ${ }^{3}$ Salah satu jenis minuman ringan yang berkembang pesat di pasaran adalah minuman sari buah. Minuman sari buah merupakan minuman favorit masyarakat Indonesia karena bisa didapatkan dimana saja dengan alasan kepraktisannya. ${ }^{4}$ Minuman dengan kandungan buah merupakan kategori minuman terbesar keenam di dunia yang banyak dikonsumsi masyarakat. ${ }^{5} \mathrm{Di}$ Indonesia, frekuensi minum minuman sari buah setiap orang dua sampai empat kali per minggu. ${ }^{6}$

Konsumsi makanan maupun minuman berwarna dalam jangka waktu yang lama dapat menyebabkan perubahan warna pada gigi maupun resin komposit. ${ }^{7}$ Berdasarkan penelitian yang pernah dilakukan sebelumnya oleh Vivi D. terjadi perubahan warna pada resin komposit microfiller dannanofiller yang direndam larutan teh dan kopi selama satu minggu, ${ }^{8,9}$ tetapi belum pernah dilakukan penelitian perendaman resin komposit pada minuman sari buah. Berdasarkan latar belakang di atas penulis tertarik melakukan penelitian untuk melihat perbedaan perubahan warna resin komposit pada perendaman minuman sari buah pabrik dan sari buah segar.

\section{METODE PENELITIAN}

Penelitian ini menggunakan jenis penelitian eksperimen murni dengan rancangan penelitian pretest and posttest group design. Penelitian ini dilakukan di Laboratorium Kimia Fakultas MIPA Universitas Sam Ratulangi Manado pada bulan Februari sampai Agustus 2015. Subjek yang digunakan sebanyak sepuluh resin komposit yang dibentuk lingkaran dengan tebal $2 \mathrm{~mm}$ dan diameter $5 \mathrm{~mm}$. Pada penelitian ini variabel yang digunakan adalah Minuman sari buah dan Resin komposit.Alat dan Bahan yang digunakan yaitu Spektrofotometer ( BIOCHROM S12 UV/Visible ), minuman sari buah merek $\mathrm{X}$, buah jambu biji merah, resin kompositnanofillermerek Y warna A3.

\section{HASIL PENELITIAN}

Berdasarkan pengukuran yang telah dilakukan pada masing-masing sampel, dapat dilihat perubahan warna sampel

sebelum perendaman dan setelah perendaman hari ketiga, hari keenam, dan hari kesembilan (Tabel 3).

Hasil pengukuran warna awal sampel pada kedua kelompok menunjukan tingkat kecerahan yang sama yaitu 2,16. Hasil pengukuran pada hari ketiga, keenam, dan kesembilan pada kedua kelompok dapat dilihat terjadi penurunan angka kecerahan dari setiap sampel, namun terdapat satu sampel pada kelompok II yang memiliki nilai yang sama pada pengukuran hari keenam dan kesembilan.

Untuk membuktikan perubahan warna yang bermakna yang pada kedua kelompok dilakukan uji statistik, data yang diperoleh dilakukan uji normalitas Shapiro-Wilk, dan didapatkan nilai $\mathrm{p}>0,05$ berarti seluruh sampel berdistribusi normal, selanjutnya dilakukan uji t berpasangan pada kelompok I dan kelompok II (Tabel 4). Berdasarkan hasil uji $\mathrm{t}$ berpasangan pada kedua 
kelompok didapatkan nilai $\mathrm{p}<0,05$ berarti terdapat rerata perubahan warna yang bermakna sebelum dan sesudah perendaman pada hari ketiga, keenam, dan kesembilan. Selanjutnya dilakukan uji t tidak berpasangan pada kedua kelompok (Tabel 4).

Berdasarkan hasil uji t berpasangan pada kedua kelompok didapatkan nilai $\mathrm{p}<0,05$ berarti terdapat rerata perubahan warna yang bermakna sebelum dan sesudah perendaman pada hari ketiga, keenam, dan kesembilan (Tabel 4). Selanjutnya dilakukan uji t tidak berpasangan pada kedua kelompok (Tabel 5).

Tabel 3. Perubahan warna kedua kelompok yang diamati dari hari ketiga, keenam, dan kesembilan.

\begin{tabular}{lccccc}
\hline \multirow{2}{*}{ Kelompok } & Sampel & \multicolumn{5}{c}{ Hari } \\
\cline { 2 - 6 } & & 0 & 3 & 6 & 9 \\
\hline \multirow{2}{*}{ Kelompok I } & 1 & 2,16 & 1,1 & 0,9 & 0,8 \\
(Sari buah segar) & 2 & 2,16 & 1,2 & 1,0 & 0,8 \\
& 3 & 2,16 & 1,3 & 1,1 & 0,9 \\
& 4 & 2,16 & 1,4 & 1,0 & 0,7 \\
\multicolumn{1}{c}{ Rerata } & 5 & 2,16 & 1,3 & 1,0 & 0,9 \\
\hline \multirow{2}{*}{ Kelompok II } & 1 & 2,16 & $\mathbf{1 , 2 6}$ & $\mathbf{1 , 0}$ & $\mathbf{0 , 8 2}$ \\
(Sari buah pabrik) & 2 & 2,16 & 0,6 & 0,5 & 0,4 \\
& 3 & 2,16 & 0,5 & 0,4 & 0,3 \\
& 4 & 2,16 & 0,5 & 0,4 & 0,4 \\
\multicolumn{1}{c}{ Rerata } & 5 & 2,16 & 0,4 & 0,5 & 0,4 \\
\hline
\end{tabular}

Tabel 4. Hasil uji t berpasangan kelompok I dan kelompok II

\begin{tabular}{ccccc}
\hline Satuan waktu & \multicolumn{2}{c}{ Kelompok I (Segar) } & \multicolumn{2}{c}{ Kelompok II (Pabrik) } \\
(Hari) & Rerata \pm SD & P & Rerata \pm SD & P \\
\hline $0-3$ & $0,900 \pm 0,116$ & $<0,000$ & $1,640 \pm 0,080$ & $<0,000$ \\
$3-6$ & $0,260 \pm 0,089$ & $<0,003$ & $0,120 \pm 0,044$ & $<0,004$ \\
$6-9$ & $0,180 \pm 0,083$ & $<0,009$ & $0,080 \pm 0,044$ & $<0,016$ \\
\hline
\end{tabular}

Tabel 5. Hasil uji t tidak berpasangan

\begin{tabular}{cccc}
\hline \multicolumn{2}{c}{ Rerata \pm SD } & $\begin{array}{c}\text { Perbedaan rerata } \\
\text { (IK 95\%) }\end{array}$ & P \\
Kel I (Segar) & Kel. II (Pabrik) & $0,600(0,475-0,724)$ & $<0,000$ \\
\hline $0,426 \pm 0,109$ & $1,026 \pm 0,205$ & 0,675 \\
\hline
\end{tabular}

Dari hasil uji statistik yang dilakukan menggunakan uji $\mathrm{t}$ tidak berpasangan terlihat bahwa nilai $\mathrm{p}<0,05$ berarti terdapat perbedaan rerata perubahan warna pada resin komposit yang direndam pada minuman sari buah pabrik dan sari buah segar.

\section{BAHASAN}

Berdasarkan penelitian yang telah dilakukan didapatkan hasil pengukuran warna awal sampel pada kedua kelompok menunjukkan tingkat kecerahan tiap sampel adalah sama. Pada pengukuran hari ke-3, 6, 9 didapatkan angka kecerahan tiap 
sampel yang terus menurun setiap pengukurannya semakin rendah nilai yang didapat menunjukan warna sampel semakin gelap. Hasil penelitian ini sejalan dengan penelitian yang telah dilakukan sebelumnya oleh Manangkalangi ${ }^{10}$ tahun 2014 di Manado yang menunjukan bahwa semakin lama waktu perendaman komposit dengan kopi akan semakin besar perubahan warna yang terjadi pada resin komposit.

Perubahan warna pada kelompok sari buah segar secara kasat mata tidak kelihatan, tetapi dengan spektrofotometer didapatkan hasil adanya perubahan warna yang terjadi pada sampel. Hasil pengukuran hari kesembilan pada kelompok sari buah pabrik menunjukkan adanya salah satu sampel yang memiliki angka penurunan tetap seperti pada pengukuran hari sebelumnya. Hasil pengukuran yang didapatkan bervariasi dan ini mungkin terjadi karena perbandingan kandungan cairan dari sari buah pabrik maupun sari buah segar yang direndam pada masingmasing sampel tidak sama, walaupun takaran dari larutan tersebut sama banyaknya pada masing-masing wadah tempat sampel direndam.

Perubahan warna pada sampel yang direndam dalam minuman sari buah pabrik mungkin terjadi karena adanya zat warna yang terkandung dalam minuman sari buah pabrik. Salah satu kandungan zat warna yang terdapat dalam minuman sari buah pabrik yaitu karmin. Seperti pada kopi, zat warna yang terkandung dalam minuman tersebut menyebabkan terjadinya perubahan warna pada resin komposit.

Peningkatan perubahan warna pada sampel dapat terjadi karena adanya penyerapan air oleh resin komposit yang disebabkan oleh matriks resin yang bersifat hidrofilik, sehingga matriks resin mampu menyerap cairan di sekitarnya. ${ }^{10}$ Penyerapan cairan oleh komposit ini akan diikuti oleh penyerapan substansi lain dari cairan tersebut termasuk zat warna yang terkandung dari cairan itu.

Pada perendaman kedua kelompok dalam minuman sari buah pabrik dan sari buah segar, masing-masing sampel dari kedua kelompok ini menunjukan adanya perubahan warna dan perubahan yang bermakna $\mathrm{p}<0,05$ terjadi pada kelompok sari buah pabrik. Pada hasil uji $t$ berpasanganpada kelompok I dan pada kelompok II nilai p yang didapat yaitu p < 0,05 yang menunjukkan adanya perbedaan rerata yang bermakna sebelum dan sesudah perendaman hari ke-3, 6, dan 9. Pada hasil uji $\mathrm{t}$ tidak berpasangan menunjukkan bahwa nilai $\mathrm{p}$ yaitu $0,000(\mathrm{p}<0,05)$ yang berarti terdapat perbedaan rerata perubahan warna resin komposit yang direndam dalam minuman sari buah segar dan sari buah pabrik, dan rerata perubahan warna yang lebih besar terdapat pada kelompok sari buah pabrik.

Penelitian ini memiliki keterbatasan yaitu tidak dilakukan penelitian pendahuluan untuk mengetahui komposisi sari buah pabrik, seperti perisa jambu dan bahan pengawet yang mungkin berpengaruh terhadap perubahan warna pada resin komposit.

\section{SIMPULAN}

1. Terdapat perubahan warna resin komposit yang bermakna pada perendaman minuman sari buah.

2. Perubahan warna resin komposit yang direndam minuman sari buah pabrik lebih besar dibandingkan dengan sari buah segar.

\section{SARAN}

Perlu adanya penelitian lanjut dengan membandingkan resin komposit dari beberapa merek.

Terima kasih penulis ucapakan kepada dr. D. H. C. Pangemanan, Mkes, AIFM, AIFO, drg. Christy Mintjelungan, MKes, serta kepada semua pihak yang baik secara langsung maupun tidak langsung telah menumbuhkan ide atau gagasan dalam pemikiran penulis sehingga dapat menyelesaikan artikel ini.

\section{DAFTAR PUSTAKA}

1. Baum, Philips, Lund. Buku ajar ilmu konservasi gigi, Alih bahasa Rasinta 
T, ed. 3. Jakarta: EGC, 1997; p. 25663.

2. Megumi F, Kawakami S, Noda M, Hidehiko. Color stability of newly developed esthetic restorative material immersed in food simulating solution. Dent Mater J. 2006;25(2): 352-3.

3. Direktorat jendral bea cukai. Kajian terhadap minuman ringan sebagai calon barang kena cukai dalam rangka ekstensifikasi objek barang kena cukai. 2002. Available from: URL:

http://www.beacukai.go.id/library/dat a/softdrink.html. Diakses 30 april 2015.

4. Fatiyah, Sumarwan U, Tanziha I. Analisis pengetahuan gizi dan produk minuman sari buah kemasan dihubungkan dengan merek yang dikonsumsi pada mahasiswa IPB. Jurnal Media Gizi \& Keluarga. 2005;29(2):75-87.

5. Anonim. 10 minuman terenak di dunia. [Online] 2013 Juni. Available from: URL:

http://www.tahupedia.com/content/sh ow/201/10-Minuman-Terenak-diDunia. Diakses 30 April 2015.

6. Nusasearch. Laporan mengenai minuman sari buah di indonesia. [Online] 2013 Januari. Available from: URL: http://nusaresearch.net/public/news/7 28- laporan_mengenai_kebiasaan_mengk onsumsi_minuman_jus_buah.nsrs. Diakses 30 April 2015.

7. Anonim. Mengatasi gigi kuning dan bau mulut. [Online] 2015 Juni.

Available from: URL: http://health.kompas.com/read/2012/0 7/19/11120954/Mengatasi.Gigi.Kunin g.dan.Bau.Mulut. Diakses 30 april 2015.

8. Vivi D. Perubahan warna resin komposit microfiller dan nanofiller yang direndam larutan teh [Skripsi]. Jember: Universitas Jember; 2013.

9. Chumairo SM. Pengaruh kebiasaan minum kopi robusta (coffea robusta) terhadap perubahan warna pada restorasi resin komposit nanfiller [Skripsi]. Jember: Universitas Jember; 2014.

10. Manangkalangi A. Pengaruh lama perendaman kopi robusta terhadap perubahan warna resin komposit [Skripsi]. Manado: Universitas Sam Ratulangi; 2014.

11. Adiguna PG. Pengaruh konsentrasi kopi terhadap perubahan warna resin komposit [Skripsi]. Denpasar: Universitas Mahasaraswati Denpasar; 2014.

12. Banerjee A, Watson FT. Pickard manual konservasi restoratif ed. 9. Jakarta: EGC, 2014; p. 89. 